\title{
Glacier extent in a Novaya Zemlya fjord during the "Little Ice Age" inferred from glaciomarine sediment records
}

\author{
JaapJan Zeeberg, Steven L. Forman \& Leonid Polyak
}

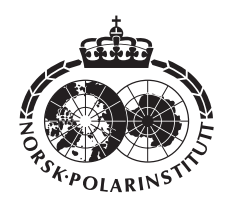

Glacier activity at Russkaya Gavan', north-west Novaya Zemlya (Arctic Russia), is reconstructed by particle size analysis of three fjord sediment cores in combination with ${ }^{14} \mathrm{C}$ and ${ }^{210} \mathrm{~Pb}$ dating. Down-core logging of particle size variation reveals at least two intervals with sediment coarsening during the past eight centuries. By comparing them with reconstructions of summer temperature and atmospheric circulation, these intervals are interpreted to represent two cycles of glacier advance and retreat sometime during ca. AD 1400-1700 and AD 1700-present. Sediment accumulation thus appears to be sensitive to century-scale fluctuations of the Barents Sea climate. The identification of two glacier cycles in the glaciomarine record from Russkaya Gavan' demonstrates that during the "Little Ice Age" major glacier fluctuations on Novaya Zemlya occurred in broad synchrony with those in other areas around the Barents Sea.

J. J. Zeeberg, Netherlands Institute for Fisheries Research, Haringkade 1, Box 68, 1970 AB IJmuiden, The Netherlands,jzeebe1@uicalumni.org; S.L.Forman, Dept. of Earth and Environmental Sciences, University of Illinois at Chicago, 845 W. Taylor Street, Chicago, IL 60607-7059, USA; L. Polyak, Byrd Polar Research Center, Ohio State University, 1090 Carmack Rd., 108 Scott Hall, Columbus, OH 43210-1002, USA.

Climate variability in the Eurasian Arctic is significantly modulated by North Atlantic oceanic heat flux. Weather stations on Novaya Zemlya since 1961 document summer temperatures $0.3-0.5^{\circ} \mathrm{C}$ and winter temperatures $2.3-2.8^{\circ} \mathrm{C}$ lower than in the first half of the 20th century (Zeeberg \& Forman 2001). This temperature decrease is associated with a prolonged negative phase of the North Atlantic Oscillation (NAO), decreased advection of North Atlantic Water, and below-average southern Barents Sea sea surface temperature (SST) during the 1960s, '70s and '80s (Loeng 1991; Zeeberg \& Forman 2001). Likewise, post-"Little Ice Age" warming of the Barents Sea and glacier retreat on northern Novaya Zemlya is associated with a persistent positive phase of the NAO.

Meteorological observations at the polar station Russkaya Gavan', north-west Novaya Zemlya (76 $11^{\prime}$ N, 59 ${ }^{\circ}$ E, Fig. 1), between 1932 and 1995 are concurrent with a mass balance time series on the adjacent Shokal'ski Glacier from 1933 to 1969. Stabilization and advance of several tidewater glaciers at Novaya Zemlya in the second half of the 20th century reflects decreased summer temperatures and/or increased precipitation (Koryakin 1986; Zeeberg \& Forman 2001). Elevated winter precipitation (up to $20 \mathrm{~mm}$ above the $27 \mathrm{~mm}$ average) associated with increased cyclonic activity, together with slowing calving rates, arrested the negative mass balance of the Shokal'ski Glacier between 1959 and 1966. Observations during the 20th century indicate, however, that continued regional warming and summer temperature anomalies less than $<1{ }^{\circ} \mathrm{C}$ compensate for the added precipitation, resulting in negative mass balances and glacier retreat (Chizov et al. 1968; Zeeberg \& Forman 2001).

Here we evaluate fjord sediment records as proxy for decade- to century-scale fluctuations of a tidewater glacier on north-west Novaya Zemlya. This analysis is based on the inference that 


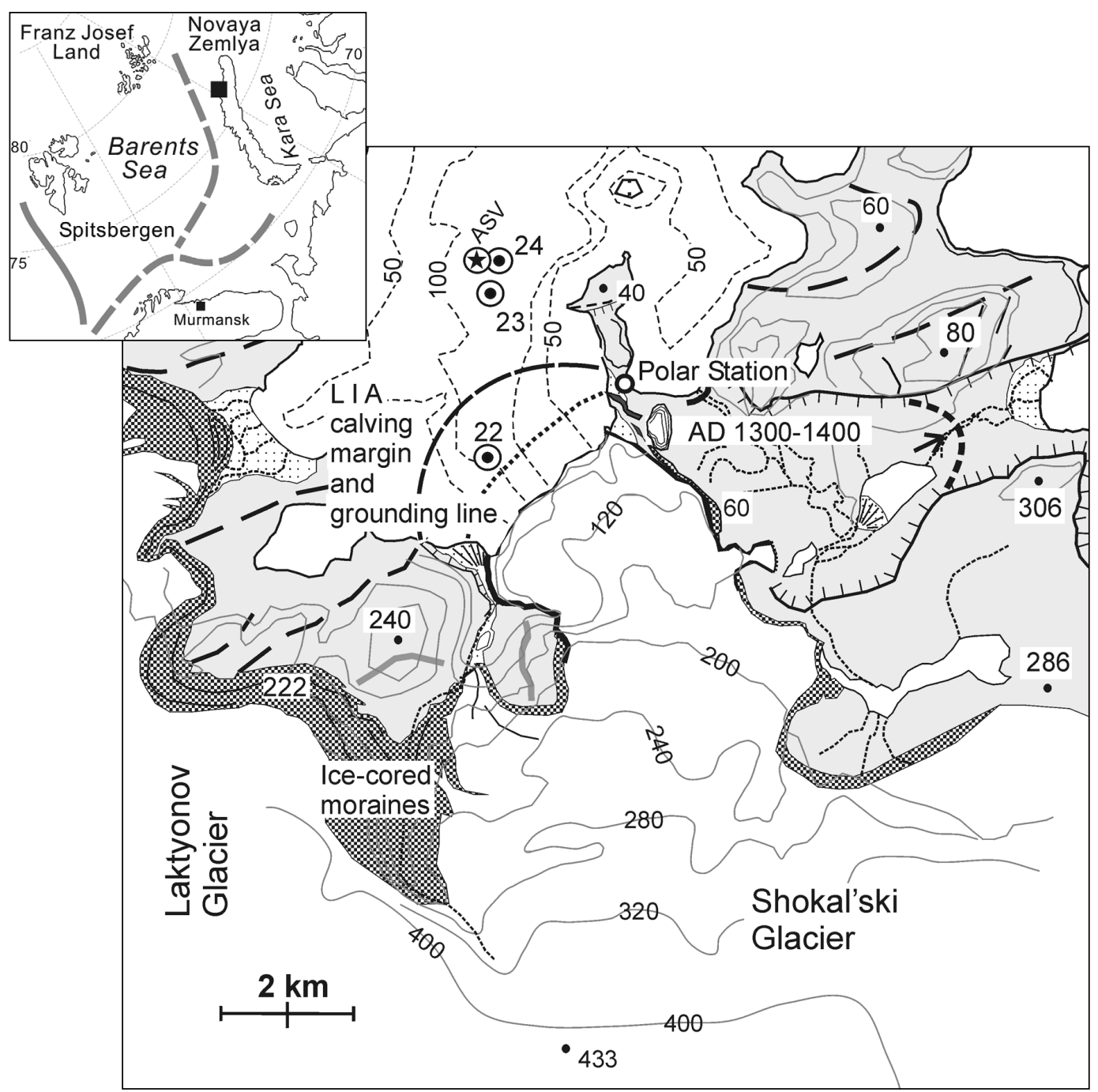

Fig. 1. Russkaya Gavan' with Shokal'ski and Laktyonov glaciers. The positions of cores IP98-22, 23 and 24 and the position of Core ASV-987 (indicated by a star) are shown. The long dashed line shows the inferred maximum glacier extent in the past 600 years. A shell obtained from the end moraine that indicates the "Little Ice Age" grounding line (short dashed line) of the Shokal'ski Glacier was dated to AD 1300-1400. Inset: pathways of North Atlantic Water along the Barents shelf and across the Barents Sea. The black block on Novaya Zemlya indicates the location of Russkaya Gavan'.

the glacial-marine record predominantly reflects meteorological and glacier-specific modulations of sediment input (see Elverhøi et al. 1983; Smith \& Schafer 1987; Syvitski et al. 1987; Cowan et al. 1988; Gilbert 2000). To assess changes in sedimentation, particle size variation was measured for three $1.2 \mathrm{~m}$ long gravity cores from Russkaya Gavan', a > $100 \mathrm{~m}$ deep, $10 \mathrm{~km}$ long fjord, dominated by the Shokal'ski Glacier (Fig. 1). Cores were retrieved at ca. $1 \mathrm{~km}$ (IP98-22), ca. $3.3 \mathrm{~km}$
(IP98-23) and ca. $3.8 \mathrm{~km}($ IP98-24) from the present glacier terminus (Figs. 1, 2). A second glacier (Laktyonov Glacier), which does not terminate in the fjord, may also contribute to fjord sedimentation through meltwater streams. Sediment accumulation in Russkaya Gavan' may record glacier response to climate change during the "Little Ice Age" and other neoglacial events that have been widely recognized in the Barents Sea region and Scandinavia (e.g. Matthews 1991; 


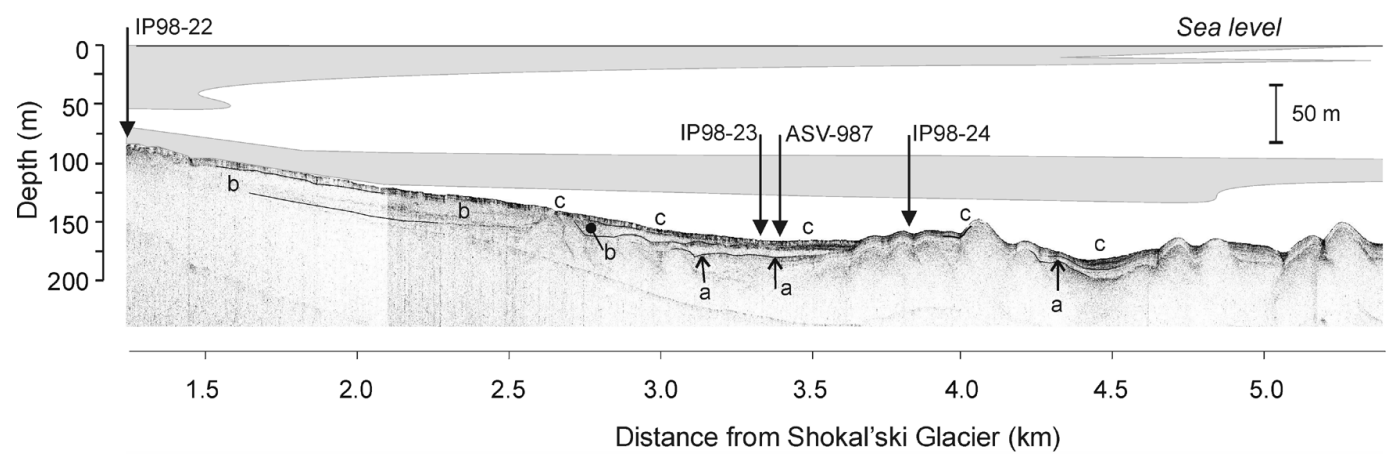

Fig. 2. Sonar ( $8.8 \mathrm{kHz})$ profile of Russkaya Gavan', showing turbid layers measured in the fjord and the locations of the IP98 and ASV-987 gravity cores. The acoustic profile demonstrates that a thin $(<10 \mathrm{~m})$ sedimentary cover (reflector c) is draping another reflector $(\mathrm{a}, \mathrm{b})$ along the fjord, with accumulation up to $30 \mathrm{~m}$ thick in topographic depressions. Reflector ( $\mathrm{a}, \mathrm{b})$ is probably a glacigenic diamicton.

Werner 1993; Lubinski et al. 1999).

\section{Methods}

\section{Core collection at Russkaya Gavan'}

Geological sampling and oceanographic measurements were performed in September 1998 from the RV Ivan Petrov. The glacial marine succession sampled by the IP-98 gravity cores is indicated by an $8.8 \mathrm{kHz}$ sonar profile of the sea floor (Fig. 2). A thin (<10 m) sedimentary cover (reflector c) drapes the surface of another reflector $(a, b)$, probably a glacigenic diamicton. Thicker sedimentary sequences (ca. $30 \mathrm{~m}$ ) can be seen in topographic depressions. At the location of one of the cores, IP98-23, an hermetically sealed box core was obtained to assure collection of the sediment-water interface needed for ${ }^{210} \mathrm{~Pb}$ dating. A 6 $\mathrm{m}$ long gravity core (ASV-987) obtained and sampled in 1997 provides additional information on depositional variability within the fjord (Polyak et al. in press).

Observations of water turbidity and conductivity, temperature and depth (CTD) measurements in Russkaya Gavan' in conjunction with the 1998 cruise indicate that meltwater is discharged from subglacial or englacial channels at the fjord head. The density difference between seawater and freshwater is $24-28 \mathrm{~kg} / \mathrm{m}^{3}$, causing rapid rise of the freshwater plume and settling of coarse-grained sediments in the resulting zone of deceleration, while fine fractions are dispersed throughout the fjord (Elverhøi et al. 1983; Syvit- ski et al. 1987; Gilbert 2000). A light transmissivity profile and sampling of suspended matter demonstrates turbid layers along the sea surface and bottom of Russkaya Gavan' (Fig. 2). Suspended sediment loads decrease ca. $2 \mathrm{~km}$ beyond cores 23, 24 and ASV-987. The spatial extent and coarseness of the plume principally reflects glacier position, meltwater production, and fjord hydrodynamics (Syvitski et al. 1987: 111-174).

\section{Lithology}

Cores IP98-22, 23, and 24 consist of homogeneous silty-mud with centimetre- to millimetre-scale lamination and incidental clasts of icerafted debris (IRD; Fig. 3). Oxidation of organic carbon was indicated after core splitting by release of $\mathrm{H}_{2} \mathrm{~S}$ and black colouration. Beds with diffuse lamination $10-20 \mathrm{~cm}$ thick alternate with beds that have fine lamination highlighted by reduced (black) monosulphides. Monosulphide beddings are most pronounced in IP98-23, suggesting periodic increase of clastic deposition alternating with settling of organic matter. The lower half of core 22 is more compact than the upper half and has two noticeable sandy layers.

Down-core fluctuations of grain size were established with a Malvern particle size analyser (Mastersizer 2000, Hydro2000 MU), which measures grain diameters by laser diffraction while a subsample in liquid suspension is pumped through a recirculating cell. Cores 23 and 24 were sampled at $1 \mathrm{~cm}$ intervals, and core 22 at $2 \mathrm{~cm}$ intervals because of expected increase of accumulation rates with proxim- 
(a)

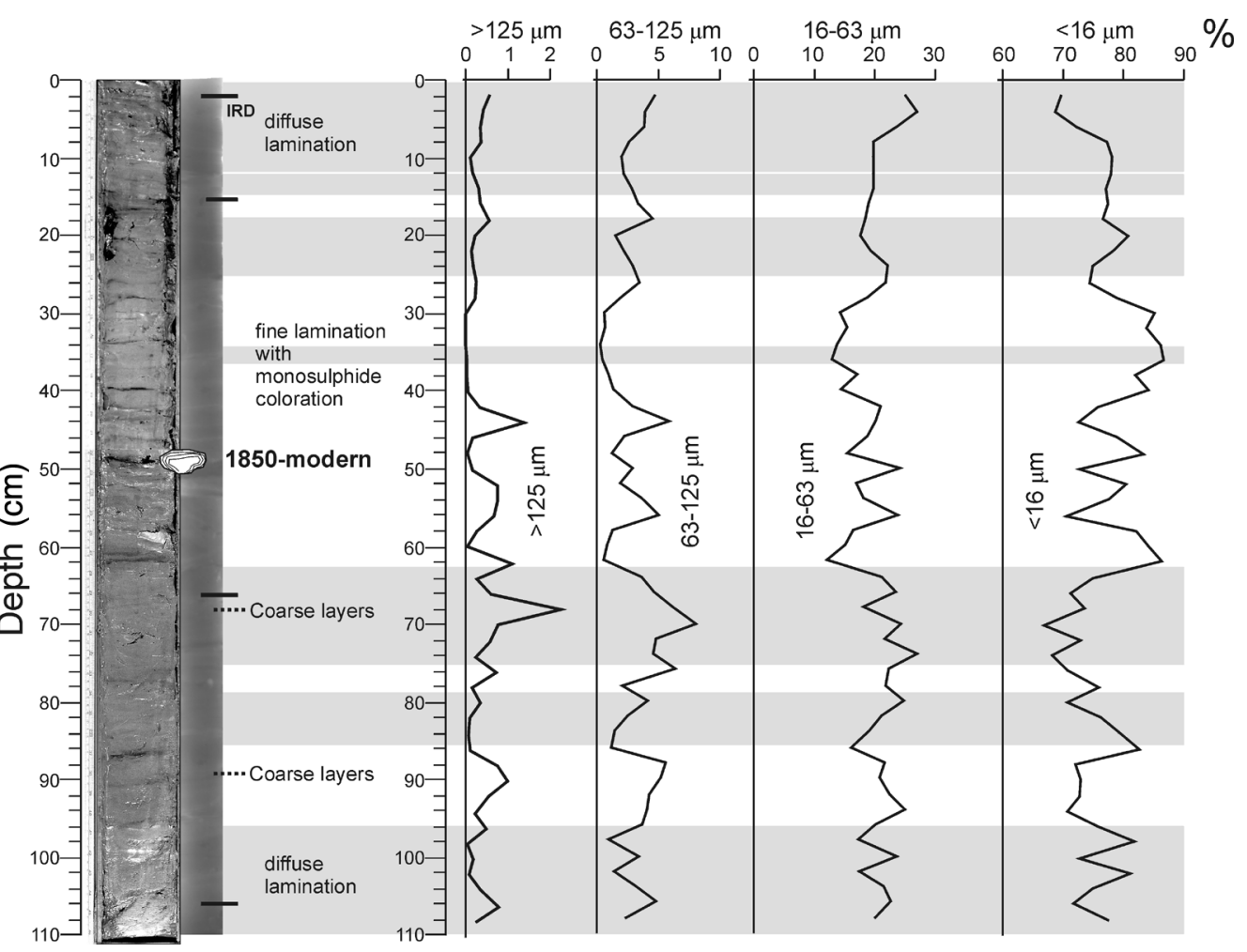

(b)

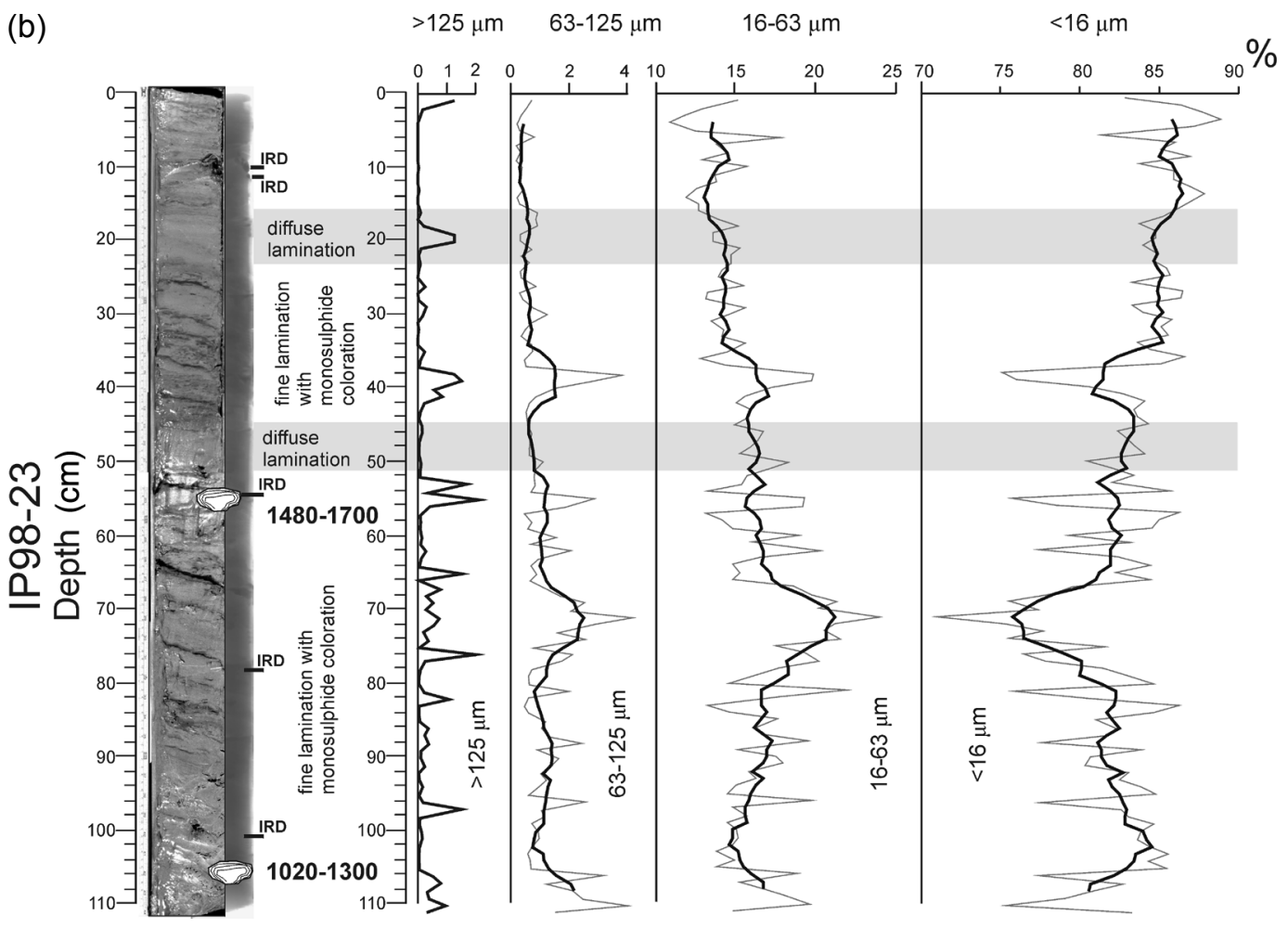




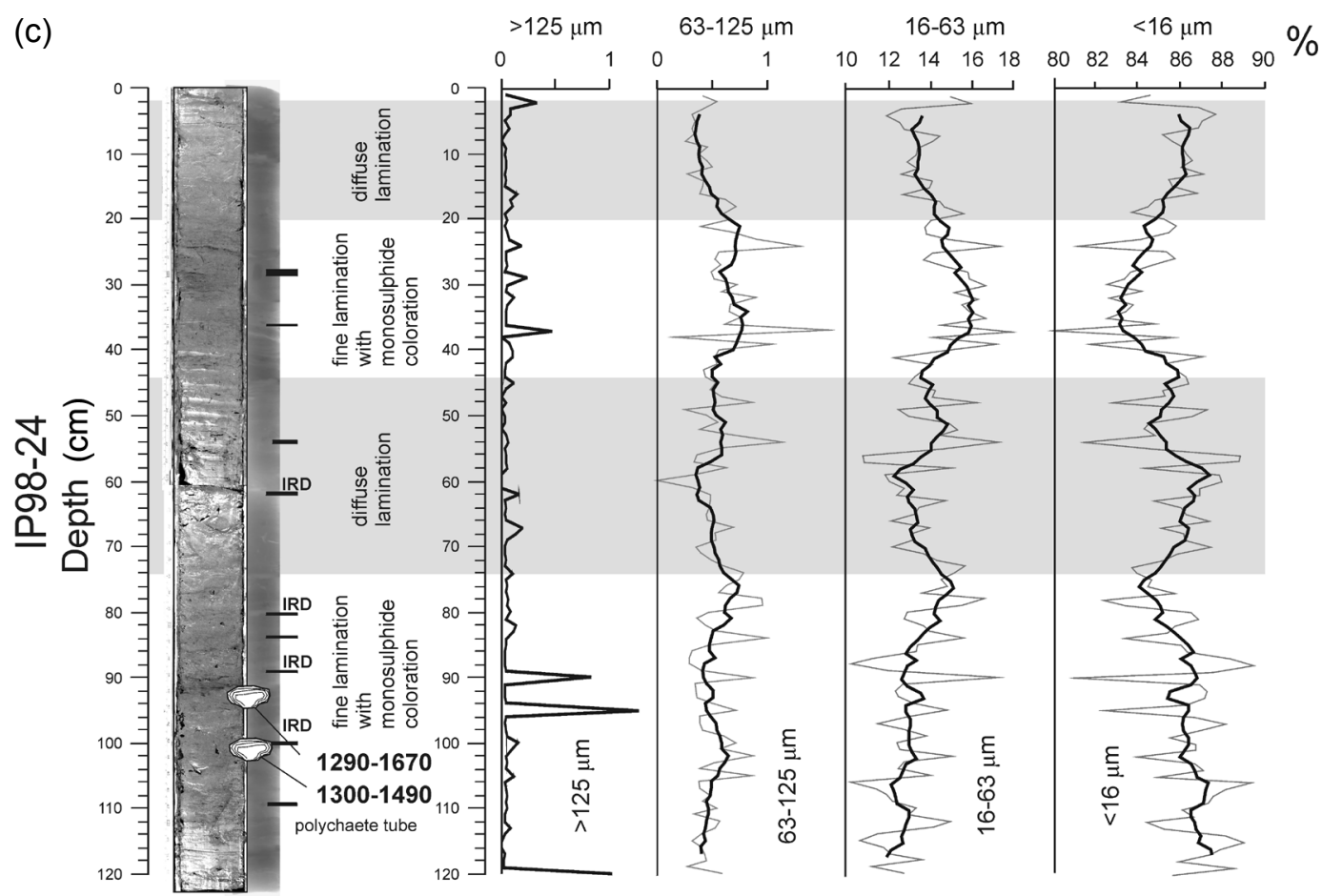

Fig. 3. Plots of grain size percentages with depth for cores (a, opposite page) IP98-22, (b, opposite page) 23, and (c) 24. From left to right are shown contents of sand, silt, and clay grouped in ranges (Wentworth scale): 1) coarser than fine sand, 2) coarse silt and fine sand, 3) medium to coarse silt, 4) fine silt and clay. Core photographs were taken immediately after core splitting to preserve black colouration of layering caused by reduced monosulphides. The core "shadows" in this figure (images to the right of the photographs) are composite X-radiographs used to identify molluscs and IRD.

ity to the glacier. Marine carbonates and organics were removed during sample preparation by adding $\mathrm{HCl}(10 \%)$ and $\mathrm{H}_{2} \mathrm{O}_{2}(30 \%)$, respectively. When reactions ceased, the mixture was diluted with distilled water before addition of a dispersant (ca. $0.3 \mathrm{~g} \mathrm{Na}_{4} \mathrm{P}_{2} \mathrm{O}_{7} \cdot 10 \mathrm{H}_{2} \mathrm{O}$ ). A subsample was then taken with a pipette while stirring and released in the sample tank of the Mastersizer. To separate remaining particle agglomerations, ultrasonics were applied for $10 \mathrm{~s}$. Instrument settings were held constant with laser obscuration at approximately $15 \%$ and a pump speed of 2500 rpm. Each sample yielded an apparent Gaussian distribution of particle sizes. Plotted in Fig. 3 are particle size ranges as volumetric percentages of the total sample and the particle size of the 90th percentile (d90). The d90 shows fluctuation of the coarse tail of the distribution (Fig. 5), registering particle size fluctuations more sensitively than, for example, the median (d50).

Fine silt and clay (Wentworth scale: fractions $<16 \mu \mathrm{m}$ ) predominate in each core, comprising
$80-90 \%$ of core 24 (the most distal core), and $70-90 \%$ in cores 22 and 23 (Fig. 3). Median particle size is $7.6 \mu \mathrm{m}$ for core $22,7.1 \mu \mathrm{m}$ for core 23 and $6.7 \mu \mathrm{m}$ for core 24 , reflecting a decrease of coarse fractions away from the glacier. This trend is also observed in other studies of glaciomarine sediments (e.g. Gilbert 2000; Desloges et al. 2002). The particle size analysis demonstrates that coarse silt and sand (fractions 63-125 $\mu \mathrm{m}$ and $>125 \mu \mathrm{m})$ comprise up to $12 \%$ of core 22 , compared to $<6 \%$ in core 23 and $<2 \%$ in core 24 . In cores 23 and 24 finely laminated beds are somewhat (respectively 10 and $2 \%$ ) enriched in coarse sediments (medium to coarse silt and fine sand). IRD occurs throughout each core as incidental, $<10 \mathrm{~mm}$ long angular to subangular rock fragments. IRD is notably abundant in the lower half of core 24. The largest IRD fragments are 20 $\mathrm{mm}$ in core 23 (depth $12 \mathrm{~cm}$ ) and core 24 (depth $61 \mathrm{~cm})$. 

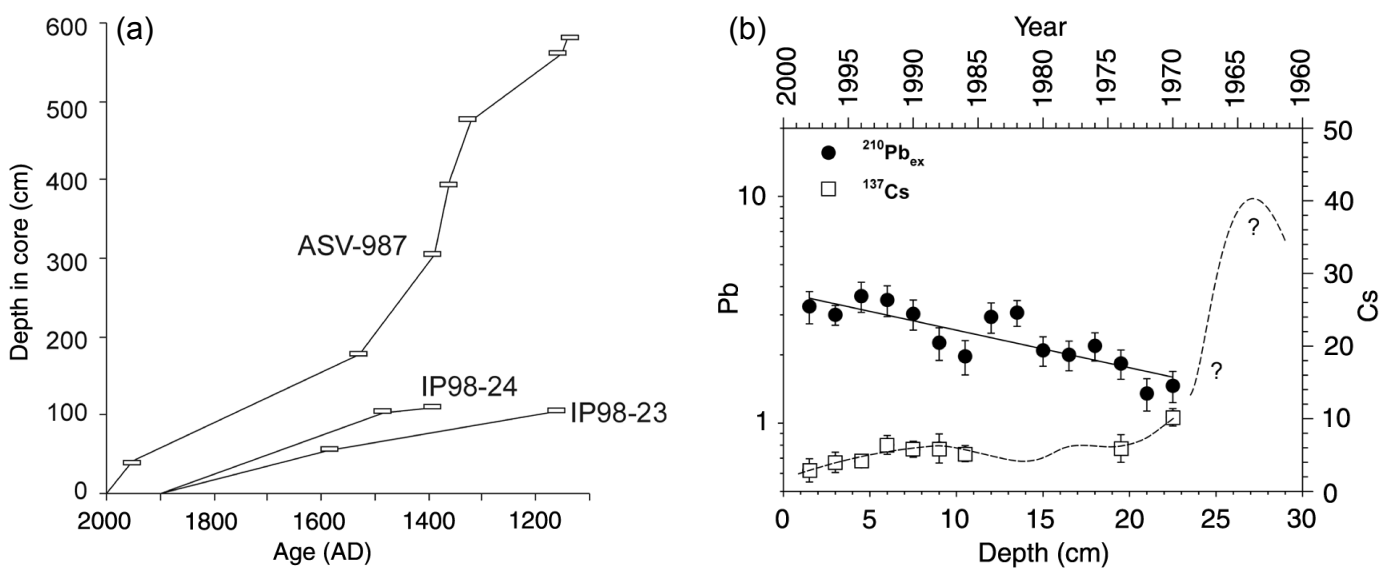

Fig. 4. (a) Age model for the IP98 and ASV-987 cores based on calibrated ${ }^{14} \mathrm{C}$ ages obtained from molluscs. (b) Modern sedimentation rates in Russkaya Gavan' are derived from analysis of the ${ }^{210} \mathrm{~Pb}$ decay series in a $0.3 \mathrm{~m}$ core that collected the sediment-water interface (including modern ${ }^{210} \mathrm{~Pb}$ ) at the location of IP98-23. The ${ }^{137} \mathrm{Cs}$ isotope increases down-core, consistent with elevated ${ }^{137} \mathrm{Cs}$ levels during the 1960 s and 1970 s.

\section{Results}

\section{Chronology: ${ }^{14} \mathrm{C}$ and ${ }^{210} \mathrm{~Pb}$ dating}

Radiocarbon dating of in situ molluscs from the top and base of the cores provides broad chronological control (Figs. 3, 4, Table 1), with calibrated age ranges spanning 300 to 500 years (Stuiver et al. 1998). An additional challenge for ${ }^{14} \mathrm{C}$ dating is the large and variable local marine reservoir correction. A study of bivalves from Novaya Zemlya fjords indicates a reservoir correction of $775 \pm 200 \mathrm{yr}$ for Portlandia arctica, a detrital-feeding bivalve that can burrow up to $20 \mathrm{~cm}$ into sediments and feeds on old organic matter within (Forman \& Polyak 1997). This mollusc has a broad salinity tolerance and may live close to glaciers. Hence, the large reservoir correction indicated by this shell may result from assimilation of old carbon from glacier meltwater and/or detrital organics from sediments. Suspension feeding bivalves (e.g. Astarte sp., Macoma sp.) are also common in glaciomarine sediments from Russkaya Gavan', and previously yielded a reservoir age of ca. $400 \pm 100$ yr (Forman \& Polyak 1997; see also Heier-Nielsen et al. 1995).

Excess ${ }^{210} \mathrm{~Pb}$ activity measurements on unconsolidated near-surface sediments provide a more precise age model for the past century than ${ }^{14} \mathrm{C}$ (e.g. Smith \& Schafer 1987; Hughen et al. 2000). Linear regression of ${ }^{210} \mathrm{~Pb}$ on depth in a $30 \mathrm{~cm}$ sealed core retrieved with IP98-23 gives a sed- imentation rate of $8 \mathrm{~mm} / \mathrm{yr}$, assuming a ${ }^{226} \mathrm{Ra}$ background of $1.5 \mathrm{dpm} / \mathrm{g}$ (Fig. 4). ${ }^{210} \mathrm{~Pb}$ dating is often calibrated by location of the ${ }^{137} \mathrm{Cs}$ "bomb" spike. The ${ }^{137}$ Cs fallout peak was ca. 1964 , but there is often a delay of 5 to 10 years before cesium settles from the water column with sediments. Analysis of the reference core did not yield the cesium spike, which may be due to sediment mixing or low isotope concentration, because deposition from the atmosphere decreases above ca. $60^{\circ} \mathrm{N}$ (Hughen et al. 2000; J. Smith, pers. comm. 2001). The sedimentation rate derived by ${ }^{210} \mathrm{~Pb}$ analysis demonstrates that the reference core covers the 1970 s. The ${ }^{137} \mathrm{Cs}$ isotope slightly increases downcore, consistent with elevated ambient ${ }^{137} \mathrm{Cs}$ during this period (Fig. 4). In contrast to the ${ }^{210} \mathrm{~Pb}$-derived decadal rate, ${ }^{14} \mathrm{C}$ dating of consolidated sediments provides a maximum limiting chronology because of the effect of time averaging, potentially yielding sedimentation rates that are too low.

Basal ages of at least 600 years were derived by ${ }^{14} \mathrm{C}$ dating of Macoma sp. bivalves for cores IP98$23(1.12 \mathrm{~m})$ and IP98-24 $(1.24 \mathrm{~m})$. The resulting linear sedimentation rate of ca. $2 \mathrm{~mm} / \mathrm{yr}$ is comparable to rates calculated for subpolar fjords of north Spitsbergen (Elverhøi et al. 1983) and west Greenland (Desloges et al. 2002). Comparison with core ASV-987, which has a mean accumulation rate of ca. $6 \mathrm{~mm} / \mathrm{yr}$ (Polyak et al. in press) indicates substantial variability of sediment distribution within the fjord. Higher accumulation 
Fig. 5. Correlation of IP cores based on calibrated ${ }^{14} \mathrm{C}$ age ranges. Shown here is the fluctuation with depth of the grain diameter of the 90th percentile (d90, see text for explanation).
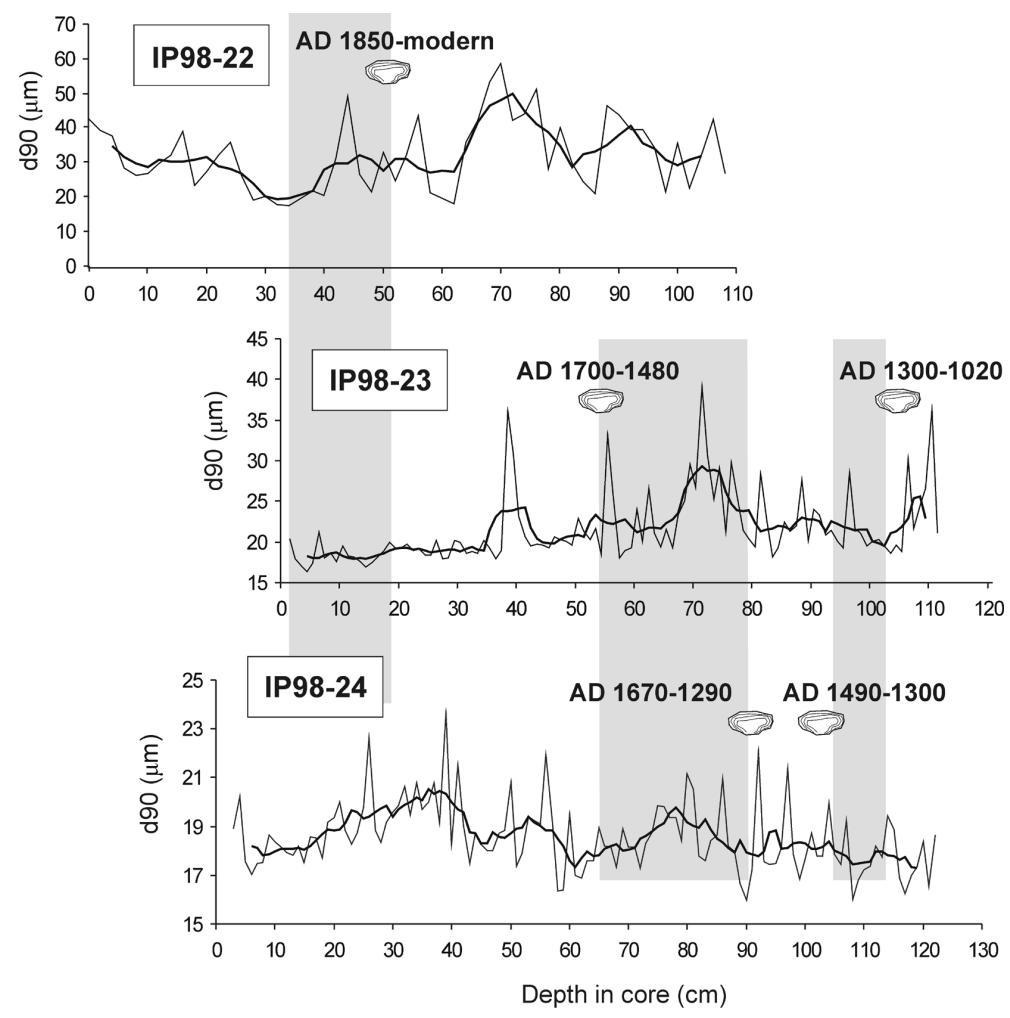

rates in ASV-987 shows that thicker sediment was sampled here, possibly reflecting additional sedimentation from the Laktyonov Glacier's fluvial delta (Fig. 1).

A mollusc at $56 \mathrm{~cm}$ in core IP98-22 yielded a submodern age, indicating a higher accumulation rate (ca. $5-10 \mathrm{~mm} / \mathrm{yr}$ ) for core 22 than for cores $23-24$, consistent with its glacier proximal position. With accumulation rates $5\left({ }^{14} \mathrm{C}\right)$ to $8\left({ }^{210} \mathrm{~Pb}\right)$ $\mathrm{mm} / \mathrm{yr}$, core 22 is probably continuous through the 19 th century. There is no ${ }^{14} \mathrm{C}$ age control for the past three centuries for IP98-23 and 24. Crosscorrelation between cores based on shell ages and peaks in the coarse fraction suggests that of IP9823 and 24 the core tops, comprising the past ca. 50 - 100 years, were lost during coring (Fig. 5).

\section{Glacier proximity in the sedimentary record}

The sediment record in Russkaya Gavan' is dominated during the past ca. 800 years by finegrained glacifluvial deposition with some input from IRD and sediment gravity flows. The exclusively clay to medium silt-sized particle ranges measured in cores 22-24 suggest that these cores were retrieved from glacier-distal environments, dominated by settling of silt and agglomerated clay particles from suspension. Coarse silts and sands (63-125 and >125 $\mu \mathrm{m}$, Fig. 3) constitute $<2 \%$ in core $24(3.8 \mathrm{~km}$ from the glacier $),<6 \%$ in core 23 (3.3 $\mathrm{km}$ from the glacier), and $<12 \%$ in core 22 ( $1 \mathrm{~km}$ away from the glacier).

Medium-grained sand is deposited within ca. $200 \mathrm{~m}$ from ice fronts in fjords of north-west Spitsbergen (Elverhøi et al. 1993). Turbulent, high energy meltwater discharge by temperate, high precipitation glaciers of south-east Alaska deposits sand within $1 \mathrm{~km}$ of the glacier terminus (Cowan et al. 1988). Hence, for the subpolar Shokal'ski Glacier we infer that the absence of medium sands $(250 \mu \mathrm{m})$ in IP98-22, obtained ca. $1 \mathrm{~km}$ from the present glacier terminus, suggests that this core was $>0.2 \mathrm{~km}$ from the grounding line at all times (Fig. 1). The increase in fractions $>125 \mu \mathrm{m}$ between 40 and $80 \mathrm{~cm}$ indicates increased meltwater discharge and/or increased glacier proximity in the mid-19th century (Figs. $3,5)$.

Limited glacier advance $(<1 \mathrm{~km})$ is consistent with an apparent absence of "Little Ice 
Age" moraines on the acoustic profile. Possible moraine ridges (see Elverhøi et al. 1983) ca. $3 \mathrm{~km}$ down the fjord were probably produced by an earlier grounding line (Fig. 2). Historical observations (Jermolaev 1934 cited in Chizov et al. 1968; also Zeeberg \& Forman 2001) indicate that during the 19th century, the floating (calving) glacier margin extended further than the grounding line and over the location of IP98-22. The glacier's limited response to climate fluctuations in the past ca. 800 years may reflect its steep areaelevation gradient (Fig. 1), making it less susceptible to changes in equilibrium line altitude (Zeeberg \& Forman 2001).

\section{Discussion}

\section{Interpretation of the grain size signal}

Suspended sediment loads in subpolar, glacierdominated fjords commonly range between 50 and $200 \mathrm{mg} / \mathrm{L}$ during summer, but in winter these loads are usually $<2 \mathrm{mg} / \mathrm{L}$ (Syvitski et al. 1987: 123, 134). During winter, glacier melt and output of sediment with meltwater is minimal. Climate change primarily affects the length of the summer (melt) season, which for Russkaya Gavan', at sea level, has been less than two months (July and August) during the exceptionally warm 20th century ( $>1{ }^{\circ} \mathrm{C}$ anomaly; Briffa et al. 1995). The net annual mass balance may be determined during these summer months by a few melt days, and thus by cloudiness and sea ice, which limits heat transport to the region. Cold periods can be characterized by a low number of "melt years", reduced meltwater delivery, and low net sediment accumulation. Increased melt would result in increased sediment output and an increase of coarse fractions.

The ${ }^{14} \mathrm{C}$-constrained glaciomarine record from Russkaya Gavan' reveals two intervals with significant sediment coarsening and a concomitant drop of fine fractions (Fig. 3). Correlation of the cores based on ${ }^{14} \mathrm{C}$ ages reveals that these coarsening episodes were probably produced by the same cycles of glacier advance-stabilizationretreat (Fig. 5). Because the core sites characterize different sedimentation zones in the fjord, the expression of coarsening varies between cores. Thus, a narrow peak in core $23(40 \mathrm{~cm}$, coarse fraction $6 \%$ ) appears to correlate with a broader peak in core $24(35 \mathrm{~cm}$, coarse fraction $2 \%)$. The age of the lower coarsening event can be broadly estimated as between the 14th and 17th century, whereas the upper coarse interval may be about two centuries younger based on sedimentation rates of $2+\mathrm{mm} / \mathrm{yr}$. The younger coarsening event may be correlative to the coarse part of core 22 , although age control of this core is insufficient for a definitive correlation.

Table 1. Pelecypod species and ages for the IP98 cores.

\begin{tabular}{|c|c|c|c|c|c|}
\hline Depth $(\mathrm{cm})$ & $\begin{array}{l}\text { Species and } \\
\text { res. correction }\end{array}$ & $\begin{array}{c}{ }^{14} \mathrm{C} \text { age } \\
\text { (yr BP) } \\
\text { (lab. number) }\end{array}$ & $\begin{array}{l}\text { Res. corr. } \\
{ }^{14} \mathrm{C} \text { age }\end{array}$ & $\begin{array}{c}\text { Cal age (yr AD ) } \\
1 \sigma(2 \sigma) \\
\text { and probability }\end{array}$ & $\begin{array}{c}\text { Midpoint } \\
\text { plotted } \\
(1 \sigma)\end{array}$ \\
\hline \multicolumn{6}{|l|}{ Core IP98-22 } \\
\hline 56 & Portlandia biv & $290 \pm 40$ & modern & modern & 1950 \\
\hline \multicolumn{6}{|l|}{ Core IP98-23 } \\
\hline \multirow[t]{2}{*}{55} & $\begin{array}{l}\text { Portlandia biv. } \\
\quad 400 \pm 100\end{array}$ & $\begin{array}{c}1025 \pm 45 \\
(\mathrm{AA}-37278)\end{array}$ & $625 \pm 145$ & $\begin{array}{c}1270-1434(1066-1625) \\
1243-1442(0.997)\end{array}$ & \\
\hline & $775 \pm 200$ & & $250 \pm 245$ & $\begin{array}{c}1428-\bmod (1280-\bmod ) \\
1478-1698(0.573)\end{array}$ & 1588 \\
\hline 106 & Macoma biv. & $\begin{array}{c}1225 \pm 55 \\
(\mathrm{AA}-37279)\end{array}$ & $825 \pm 155$ & $\begin{array}{c}1024-1297(895-1419) \\
1147-1291(0.610)\end{array}$ & 1160 \\
\hline \multicolumn{6}{|l|}{ Core IP98-24 } \\
\hline \multirow[t]{2}{*}{102} & $\begin{array}{c}\text { Portlandia? } \\
\text { fragments } \\
775 \pm 200\end{array}$ & $\begin{array}{c}1205 \pm 45 \\
(\mathrm{AA}-37281)\end{array}$ & $805 \pm 145$ & $\begin{array}{c}1037-1376(977-1419) \\
1150-1298(0.663)\end{array}$ & \\
\hline & & & $430 \pm 245$ & $\begin{array}{c}1297-1945(1060-\mathrm{mod}) \\
1293-1675(0.946)\end{array}$ & 1484 \\
\hline 110 & $\begin{array}{l}\text { Macoma biv. } \\
400 \pm 100\end{array}$ & $\begin{array}{c}925 \pm 55 \\
(\mathrm{AA}-37280)\end{array}$ & $525 \pm 155$ & $\begin{array}{c}1296-1486(1216-1786) \\
1288-1517(0.937)\end{array}$ & 1402 \\
\hline
\end{tabular}




\section{Inferred glacial history}

Glaciers on Novaya Zemlya during the 20th century demonstrate variable response to regional warming, because increased Barents Sea SST enhance both summer ice melt and winter precipitation (Zeeberg \& Forman 2001). However, prolonged warming and summer temperature anomalies $>0.5^{\circ} \mathrm{C}$ result in a declining Shokal'ski Glacier mass balance (Chizov et al. 1968; Mikhalov \& Chizov 1970). Summer temperature anomalies are well documented by tree-ring derived temperature time series for northern Russia (Briffa et al. 1995) and temperature composites (including ice cores) for the Northern Hemisphere (Mann et al. 1999). Strongly negative summer temperature anomalies may herald the advance of glaciers on Novaya Zemlya in the early 14th century (and also in the 19th century). This is consistent with the dating of an Astarte bivalve from a subfossil moraine ridge at a distance of ca. 500 $\mathrm{m}$ from Shokal'ski Glacier's present terminus to AD 1300-1400 (Zeeberg 2001).

The abundance of IRD in the bottom half of core 24 may indicate stabilization of the advanced glacier with iceberg calving at some time between ca. AD 1300 and 1700. Glacier melt that would have ended this cycle was probably caused by increased advection of North Atlantic Water into the Barents Sea during a persistent positive phase of the NAO. Between AD 1450 and 1650 there were at least four episodes with persistent positive phase NAOs (Cook et al. 2002). A drop of North Atlantic sea level pressure is indicated by ion contents in the GISP-2 ice core after AD 1400 (Meeker \& Mayewski 2002). After ca. AD 1650 the NAO remains comparatively weak until the 20th century. Strong negative summer temperature anomalies (Briffa et al. 1995; Mann et al. 1999) in combination with increased precipitation, as suggested by strengthening of the Icelandic Low (Meeker \& Mayewski 2002), probably caused significant glacier advance on Novaya Zemlya in the 19th century. We suggest that the second glacier cycle inferred from the glaciomarine sequence from Russkaya Gavan' corresponds to the 19th century glacier maximum and subsequent decay. The coarse layers in the bottom half of core 22 may indicate turbidity currents triggered by the advancing glacier (Figs. 3, 5).

The sediment cores from Russkaya Gavan suggest two "Little Ice Age" glacier advances sometime during ca. AD 1300-1700 and AD 1700-present (Fig. 5). These events appear to be generally consistent with glacial geologic observations from other areas around the Barents Sea. Glacier advances in Franz Josef Land are constrained by ${ }^{14} \mathrm{C}$ dating of in situ mosses from glacier margins to ca. AD 1400-1600 and post-1650 (Lubinski et al. 1999). Two stages of moraine stabilization, in the 14th century and post-1700, have been described for Svalbard on the basis of lichenometry (Werner 1993). In southern Scandinavia, "Little Ice Age" maxima were reached between AD 1400 and AD 1600 (Matthews 1991). Glaciers on Svalbard, Franz Josef Land, and Novaya Zemlya attained their greatest "Little Ice Age" extent in the second half of the 19th century (Werner 1993; Lubinski et al. 1999; Zeeberg \& Forman 2001). The identification of two glacier cycles in the glaciomarine record demonstrates that sediment accumulation in Russkaya Gavan' is sensitive to century scale fluctuations of the Barents Sea climate. During the "Little Ice Age", major glacier fluctuations on Novaya Zemlya appear to have occurred in broad synchrony with those in other areas around the Barents Sea.

Acknowledgements. $-{ }^{210} \mathrm{~Pb}$ and ${ }^{137} \mathrm{Cs}$ analyses were performed by John N. Smith, Bedford Institute of Oceanography (Dartmouth, Canada). Particle size analyses were done in cooperation with Torbjörn Törnqvist (University of Illinois at Chicago). Sonar profile is reproduced courtesy of P. I. Krinitski, V. A. Gladysh, and Y. P. Goremykin (Okeangeologia, St. Petersburg, Russia). Lawrence Febo produced the X-ray images and Jeanne Jaros (both of the Byrd Polar Research Center) the core photographs. This paper benefited from reviews by J. A. Matthews and an anonymous referee. National Science Foundation award no. OPP-9796024 supported the research.

\section{References}

Briffa, K. R., Jones, P. D., Schweingruber, F. H., Shiyatov, S. G., \& Cook, E. R. 1995: Unusual twentieth-century summer warmth in a 1,000-year temperature record from Siberia. Nature 376, 156-159.

Chizov, O. P., Koryakin, V. S., Davidovich, N. V., Kanevsky, Z. M., Singer, E. M., Bazheva, V. Y., Bazhev, A. B. \& Khmelevskoy, I. F. 1968: Results of researches on the program of the International Geophysical Year. Glaciation of the Novaya Zemlya. Glaciology IX section of IGY program. No. 18. (In Russian, with English summary.) Moscow: Nauka Publishing House.

Cook, E. R., d'Arrigo, R. D. \& Mann, M. E. 2002. A well verified, multiproxy reconstruction of the winter North Atlantic Oscillation Index since AD 1400. J. Clim. 15, 1754-1764.

Cowan, E. A., Powell, R. D. \& Smith, N. D. 1988: Rainstorm- 
induced event sedimentation at the tidewater front of a temperate glacier. Geology 16, 409-412.

Desloges, J. R., Gilbert, R., Nielsen, N., Christiansen, C., Rasch, M. \& Øhlenschläger, R. 2002: Holocene glacimarine sedimentary environments in fiords of Disko Bugt, west Greenland. Quat. Sci. Rev. 21, 947-963.

Elverhøi, A., Lønne, O. \& Seland, R. 1983: Glaciomarine sedimentation in a modern fjord environment, Spitsbergen. Polar Res. 1, 127-149.

Forman, S. L. \& Polyak, L. 1997: Radiocarbon content of prebomb marine mollusks and variations in the ${ }^{14} \mathrm{C}$ reservoir age or coastal areas of the Barents and Kara seas, Russia. Geophys. Res. Lett. 24, 885-888.

Gilbert, R. 2000: Environmental assessment from the sedimentary record of high-latitude fiords. Geomorphology 32, 295-314.

Heier-Nielsen, S., Heinemeier, J., Nielsen, H. L. \& Rud, N. 1995: Recent reservoir ages for Danish fjords and marine waters. Radiocarbon 37, 875-882.

Hughen, K. A., Overpeck, J. \& Anderson, R. F. 2000: Recent warming in a 500-year palaeotemperature record from varved sediments, Baffin Island, Canada. The Holocene 10, 9-19.

Koryakin, V. S. 1986: Sokrashcheniye oledeneniya na ostrovakh Yevraziyskoy Arktiki v XX veke. (Decrease in glacier cover on the islands of the Eurasian Arctic during the 20th century.) Pol. Geogr. Geol. 10, 157-165.

Loeng, H. 1991: Features of the physical oceanographic conditions of the Barents Sea. Polar Res. 10, 5-18.

Lubinski, D. J., Forman, S. L. \& Miller, G. H. 1999: Holocene glacier and climate fluctuations on Franz Josef Land, Arctic Russia, $80^{\circ}$ N. Quat. Sci. Rev. 18, 85-108.

Mann, M. E., Bradley, R. S. \& Hughes, M. K. 1999. Northern Hemisphere temperatures during the past millennium: inferences, uncertainties, and limitations. Geophys. Res. Lett. 26, 759-762.

Matthews. J. A. 1991: The late Neoglacial ('Little Ice Age') glacier maximum in southern Norway: new ${ }^{14} \mathrm{C}$-dating evidence and climatic implications. The Holocene 1, 219-233.

Meeker, L. D. \& Mayewski, P. A. 2002: A 1400-year highresolution record of atmospheric circulation over the North Atlantic and Asia. The Holocene 12, 257-266.

Mikhalov, V. I. \& Chizov, O. P. 1970: Rezul'taty gliatsiologicheskikh issledovanii na Novoi Zemle v 1969 g. (Scientific results of the glaciological investigations on Novaya Zemlya in 1969.) Data Glaciolog. Stud. 17, 186-199.

Polyak, L., Murdmaa, I. \& Ivanova, E. in press: A highresolution, 800-year glaciomarine record from Russkaya Gavan', a Novaya Zemlya fjord, eastern Barents Sea. The Holocene.

Smith, J. N. \& Schafer, C. T. 1987: A twentieth century record of climatologically-modulated sediment accumulation rates in a Canadian fjord. Quat. Res. 27, 232-247.

Stuiver, M., Reimer, P. J., Bard, E., Beck, J. W., Burr, G. S., Hughen, K. A., Kromer, B., McCormac, F. G., Van der Plicht, J. \& Spurk, M. 1998: Intcal98 radiocarbon age calibration, 24,000-0 cal BP. Radiocarbon 40, 1041-1083.

Syvitski, J. P. M., Burrell, D. C. \& Skei, J. M. 1987: Fjords. Processes and products. Berlin: Springer Verlag.

Werner, A. 1993. Holocene moraine chronology, Spitsbergen, Svalbard: lichonometric evidence for multiple Neoglacial advances in the Arctic. The Holocene 3, 128-137.

Zeeberg, J. J. 2001: Climate and glacial history of the Novaya Zemlya Archipelago, Russian Arctic. Amsterdam: Rozenberg Publishers.

Zeeberg, J. J. \& Forman, S. L. 2001: Changes in glacier extent on north Novaya Zemlya in the twentieth century. The Holocene 11, 161-175. 